\title{
Comparison of different treatment techniques in the mandibular condyle fracture
}

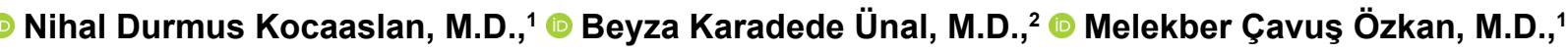 \\ Berşan Karadede, M.D., ${ }^{2}$ 을 Öhan Çelebiler, M.D. ${ }^{1}$
}

\begin{abstract}
1Department of Plastic Reconstructive and Aesthetic Surgery, Marmara University Faculty of Medicine, İstanbul-Turkey
${ }^{2}$ Department of Orthodontics, İzmir Katip Çelebi University Faculty of Dentistry, İzmir-Turkey
\end{abstract}

\begin{abstract}
BACKGROUND: Mandibular condyle fractures can be treated conservatively by intermaxillary fixation (IMF) or by open reposition and internal fixation. Although many studies have discussed for the optimal treatment method, the issue remains controversial. In this study, we aimed to compare conservative techniques in the mandibular condyle fractures.

METHODS: Twenty four unilateral condyle fracture patients aged between 18 and 48 years were treated according to one of three different modalities. Bracketing, arch bar or mini screw was applied to all non-surgery patients to obtain IMF. Eight patients were treated with only IMF meanwhile eleven patients were treated with one or double-sided amplifier occlusal splint according to the status of fractured segments, in addition to IMF. Remaining five patients have undergone open reduction and fractured segments immobilized with mini plates. Pre- and post-operative images were recorded with a computerized tomography device. Clinical and radiological examinations were performed by orthodontists and surgeons at baseline and at 6 months of treatment.

RESULTS: The condyle lengths of the patients with unilateral fracture after recovery were compared with the unaffected side. The length between the most protruding point of the condyle and the mandible was measured and the length difference was only 5.94 $\mathrm{mm}$ in patients who were treated by IMF. The length difference of patients who used brackets and splints was $3.36 \mathrm{~mm}(\mathrm{p}<0.05)$. The length difference of patients who were repaired by plate screws was $1.80 \mathrm{~mm}(p>0.05)$. However, there was no statistically significant difference $(p>0.05)$ between the groups in the IMF, occlusal splint and IMF and mini plate groups, between the trauma side and the opposite side. None of the patients developed ankylosis, open mouth, limitation of mouth opening, facial asymmetry, laterognathia, and retrognathia. The occlusion of the patients who were not known to have pre-trauma occlusions were directed, repositioned and provided an appropriate occlusion.
\end{abstract}

CONCLUSION: The use of IMF with an occlusal splint is a more conservative and acceptable treatment modality than open reduction in selected cases.

Keywords: Condyle fracture; conservative treatment; COVID- 19; pandemic; splint; temporomandibular joint.

\section{INTRODUCTION}

Among maxillofacial traumas, mandibular condylar fractures (MCFs) are one of the most controversial and special cases. MCF is one of the most common fractures of the mandible and is mostly caused by falls, violence and car accidents. ${ }^{[1-3]}$ This type of fracture can be treated conservatively by intermaxillary fixation (IMF) or by open reposition and internal fixation. Although many studies have searched for the most optimal treatment method, the issue remains controversial. ${ }^{[4}$ 6] In both types of treatment, complications such as deviation of the chin and/or facial asymmetry, ${ }^{[5,7,8]}$ reduced mandibular motility, ${ }^{[4,9]}$ dysfunction of the temporomandibular joint, ${ }^{[10,11]}$ ankylosis, ${ }^{[11]}$ chronic pain, ${ }^{[12]}$ and malocclusion ${ }^{[1,10,13-15]}$ may occur. As a result of these injuries, worsened dental occlusion, open bite, midline shift, mandibular deviation, facial asymme-

Cite this article as: Durmus Kocaaslan N, Karadede Ünal B, Çavuş Özkan M, Karadede B, Çelebiler Ö. Comparison of different treatment techniques in the mandibular condyle fracture. Ulus Travma Acil Cerrahi Derg 2022;28:99-106.

Address for correspondence: Nihal Durmus Kocaaslan, M.D.

Marmara Üniversitesi Tıp Fakültesi, Rekonstrüktif, Estetik ve Plastik Cerrahi Anabilim Dalı, İstanbul, Turkey

Tel: +90216 - 6452525 E-mail: dr-nihal@hotmail.com

Ulus Travma Acil Cerrahi Derg 2022;28(I):99-106 DOI: 10.14744/tjtes.2020.94992 Submitted: 27.06.2020 Accepted: 12.09.2020

Copyright 2022 Turkish Association of Trauma and Emergency Surgery 
try, change of condyle head position, and the most feared joint ankylosis may be seen. Therefore, it is of utmost importance to evaluate patient's signs and symptoms of trauma and to decide on the most appropriate treatment modality.

Although the incidence of condylar fractures is high, the management of MCFs is still controversial. Historically, maxillomandibular fixation, external fixation, and surgical splints with the internal fixation systems were the techniques commonly used in the treatment of the fractured mandible. Condylar fractures can be extra- or intra-capsular, non-displaced, deviated, displaced, or dislocated. ${ }^{[16]}$

Although there have been various attempts to classify condylar fractures, the classification developed by Spiessl and Schroll in 1972 has become the established standard in clinical practice. ${ }^{[17,18]}$ Spiessl and Schroll differentiate between six different types of fractures: Type I, fracture with no dislocation; Type II, inferior condylar neck fracture with dislocation; Type III, superior condylar neck fracture with dislocation; Type IV, inferior condylar neck fracture with luxation; Type $\mathrm{V}$, superior condylar neck fracture with luxation; and Type 6, intra-capsular fractures.

Many maxillomandibular fixation techniques have been developed over time, but the arch bar is the most effective one among them. IMF screws, which have been used recently, have started to create an alternative to arch bars. Although the IMF screws are much better in terms of oral hygiene compared to arch bars, they have limitations on placement without damaging the tooth roots. ${ }^{[19]}$

MCFs can be treated by conservative treatment methods, IMF, or open reduction. ${ }^{[20-23]}$ As there is no consensus on the ideal treatment of MCFs, the method to be chosen is mainly depends on the surgeon's experience and preference. ${ }^{[24,25]}$ Treatment typically depends on the age of the patient, co-existence of other mandibular or maxillary fractures, whether the condylar fracture is unilateral or bilateral, level and displacement of the fracture, status of dentition and dental occlusion. An appropriate treatment is required to reconstruct the shape and achieve the function of the uninjured status. Therefore, timely and accurate diagnosis, appropriate reduction and rigid fixation and prevention of complications are required. In particular, MCFs may lead to long-term complications such as malocclusion, particularly open bite, reduced posterior facial height, facial asymmetry, chronic pain, and mobility limitation which all requires a special caution. ${ }^{[16]}$

Although there are many methods used in trauma cases, alternative health policies are implemented in the COVID-19 pandemic, which has a great impact all over the world these days. Due to the rapid increase in the number of cases, in pandemic countries, health centers are rapidly filling their bed capacities and even trying to build new healthcare areas as capacities are exceeded. However, in some areas where healthcare providers are inadequate, the triage rules are aggravated and the treatment of cases without life threatening risk can be delayed in order not to engage in inpatient services. In other words, if we take a glance at the latest situation, other treatments are disrupted due to the increase in the number of the COVID-I9 patients worldwide and many surgical operations are delayed to an uncertain date. These decisions are strictly implemented to ensure the status of inpatient service capacities and also the possibility of cross infection can be minimized in this way. Now, one of the most important considerations today is patients' care and safety of healthcare areas due to the pandemic we are going through. During this period, although the attention of the healthcare providers is concentrated on the pandemic patients, other emergent cases are being handled as well. Although this study was conducted long before the pandemic, it can be considered as an alternative treatment method for trauma patients in healthcare institutions that are extremely concerned with pandemic patients.

In the present study, we hypothesize that there would be some difference in the complaints and symptoms between different treatment options of individuals with MCFs. We, therefore, aimed to compare conservative techniques in the condylar fractures and to identify the most optimal treatment modality based on computed tomography (CT) images.

\section{MATERIALS AND METHODS}

This retrospective study fulfilled all ethical requirements and was approved by Marmara University, School of Medicine Ethics Committee. Images of 24 patients aged between 18 and 48 years were recorded with CT device (Siemens Somatom Emotion, Siemens Medical Solutions, Erlangen, Germany) at Plastic, Reconstructive and Aesthetic Surgery Department of Marmara University, School of Medicine between January 20II and December 2016. The CT material used, in this study, was selected from the CTs in the archives previously registered for diagnostic and therapeutic purposes and located at the Radiology Department of Marmara University, School of Medicine. A total of 47 patients were diagnosed with a unilateral or bilateral condylar neck fracture. Among these 47 subjects; nine patients who did not receive any orthodontic intervention and were followed only by a soft diet, seven patients whose CT data were missing, and seven patients who had bilateral condyle fracture were excluded. Finally, Intra- and extra-oral findings of 24 patients were evaluated with clinical and radiological diagnostic equipment. CT was used for radiological diagnosis to clearly visualize the location and displacement of the fracture through the sections.

The patients with condylar neck fracture treated according to one of the three different modalities. Initially, every non-surgery patient received bracketing, archbar or IMF screws depending on patient's age and dental condition. Eight of them treated with orthodontic IMF only. Eleven patients were 


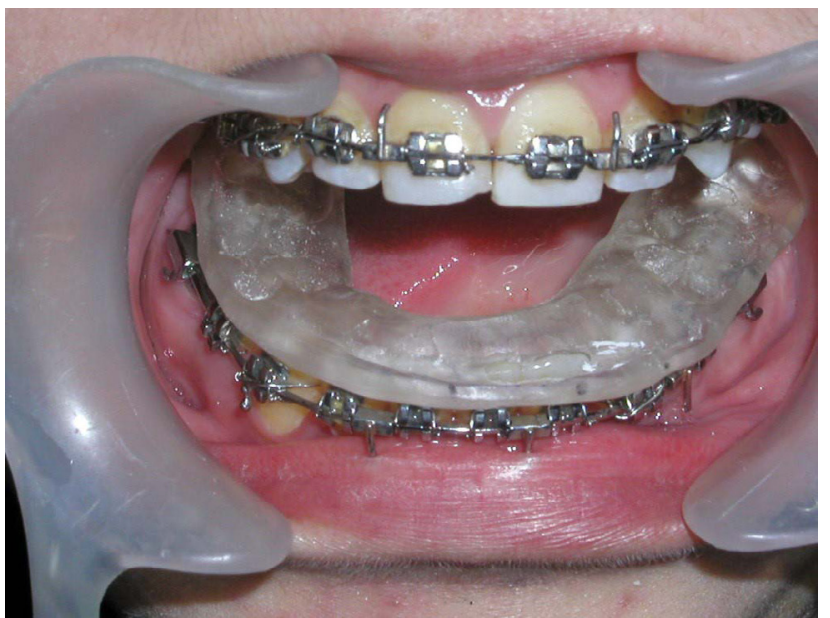

Figure 1. Amplifier occlusal splint, left side is thicker than right side to ensure the condylar length.

treated with one or double sided amplifier occlusal splint (Fig. I) according to the status of fractured segments, in addition to IMF. Remaining five patients have undergone open reduction and fractured segments immobilized with mini plates.

All patients admitted to our clinic with condylar neck fracture received a standard treatment protocol according to type of trauma as confirmed by CT. However, first-line treatment including bracketing and occlusal splints was performed by an orthodontist, in accordance with the predicted previous status of the occlusion. The operational stages were applied per protocol and the orthodontist applied the braces and special arch wire for IMF initially. For the IMF only group, the orthodontist preferred standard edge-wise brackets and 19×25 SS wire with hooks. For the IMF with occlusal splint group, after the bracketing and the arch wire were applied, the orthodon- tist took the lower and upper impressions and the models were transferred to the articulator. For the invasive intervention group, open reduction and internal fixation (ORIF) with mini-screws and plates were applied. First 10 days elastics were worn full time, next 2 weeks patients were allowed to remove elastics while eating. Following weeks, elastic wear time was $15 \mathrm{~h}$ a day, and then reduced to $9 \mathrm{~h}$ a day eventually at the last week of recovery period. All patients were administered liquid nutrition diet.

Clinical and radiological examinations were performed by the orthodontists and plastic surgeons at the beginning of the treatment and at the end of the 6 month (Figs. 2a and b). All patients were scheduled for regular follow-ups every month for 6 months. Postoperative pain, edema, ankylosis, limited mouth opening, open bite, retrognathia, laterognathia, midline deviation, facial asymmetry, occlusal deviation, and joint sound were examined. Using the CT scans, condyle positions was re-evaluated and the length comparison was performed between intact side and recovered side of mandible (Figs. 3a andb).

The condyle length was measured through the vertical line extending from the upmost point of the condyle to the mandibular angle. The axial images of the patients were processed using the program. Axial, sagittal, and coronal sections were created from the obtained data, and all data were examined and measured on three planes. The anatomical landmarks were determined correctly on CT images to construct the planes.

\section{Statistical Analysis}

Statistical analysis was performed using the SPSS version
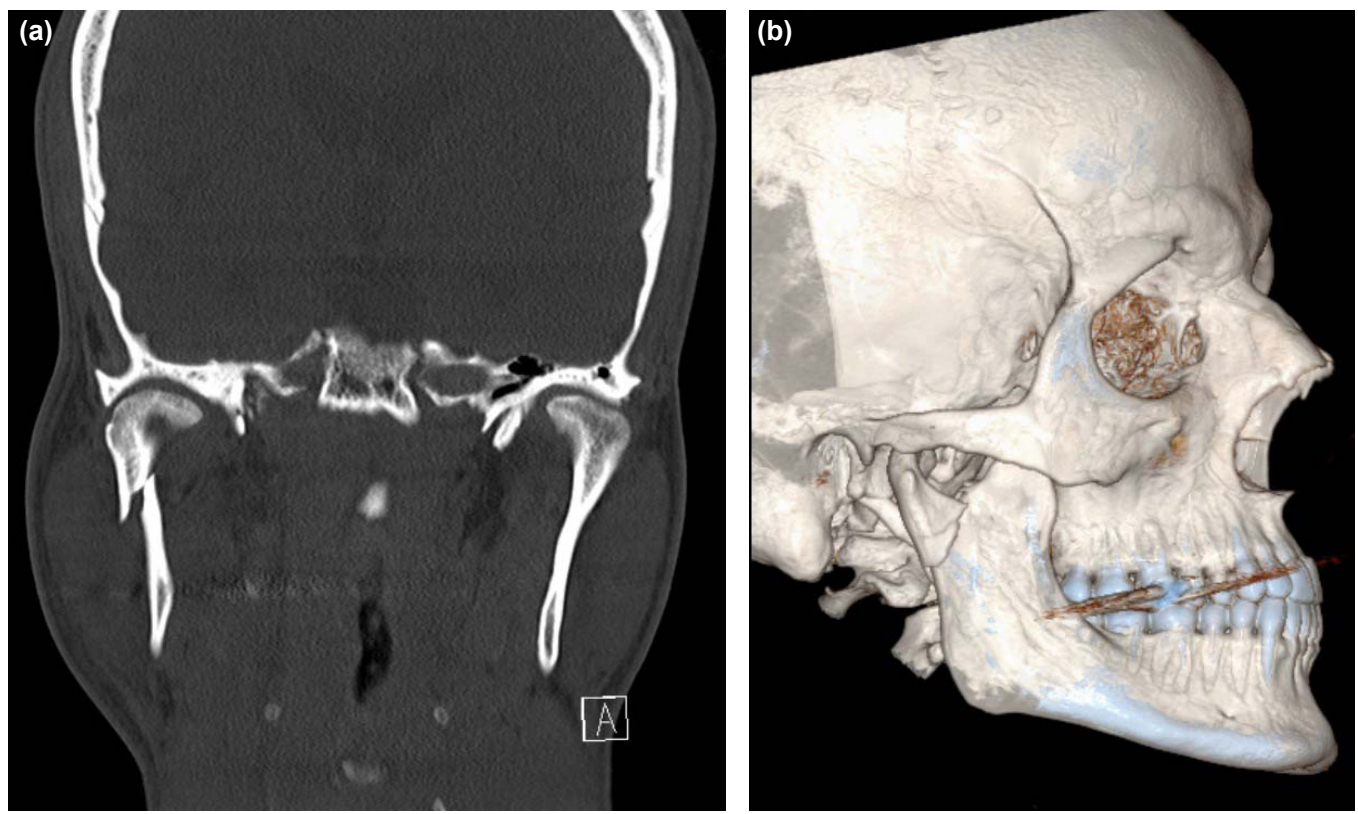

Figure 2. (a) A coronal section computed tomography view of unilateral condylar fracture before treatment. (b) A three-dimensional computed tomography view of unilateral condylar fracture before treatment. 

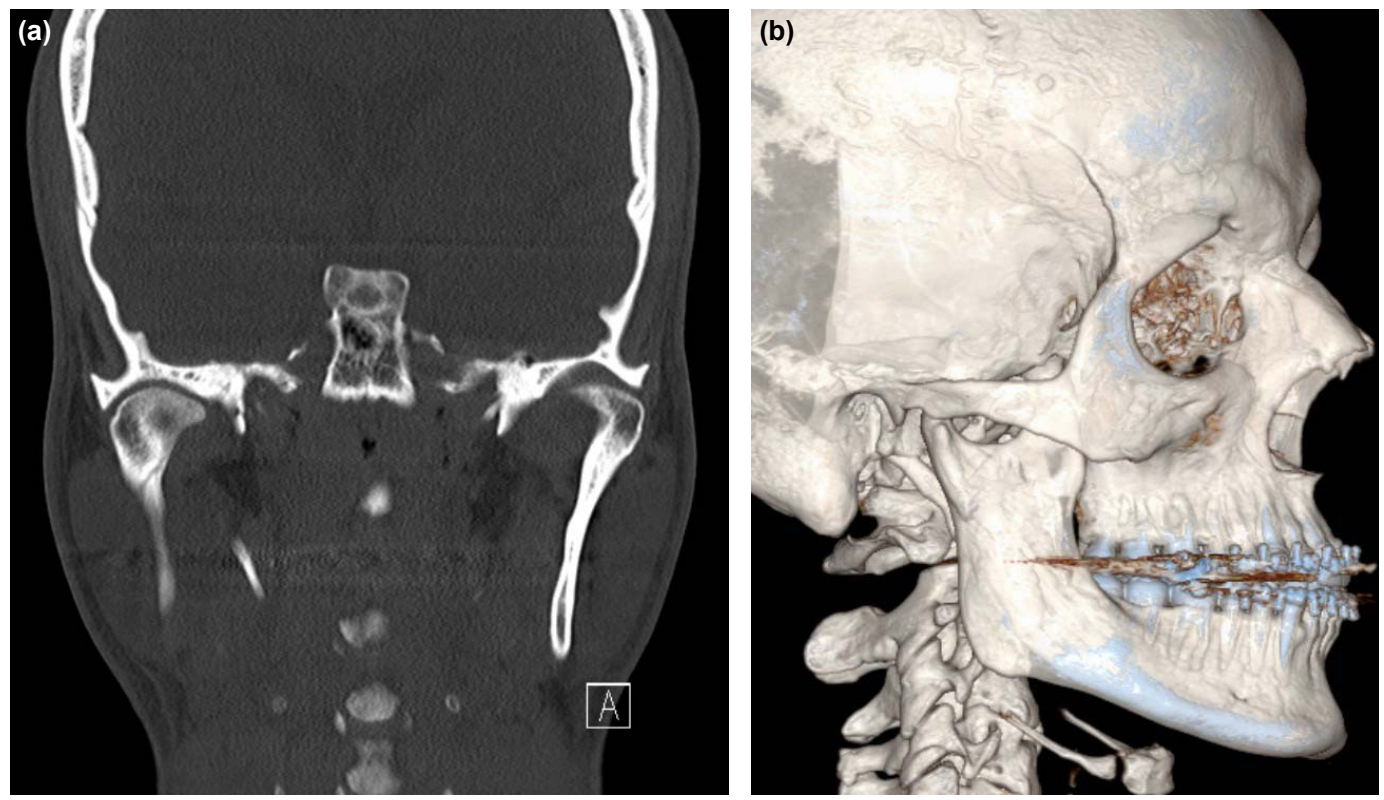

Figure 3. (a) A coronal section computed tomography view of unilateral condylar fracture after treatment. (b) A three-dimensional computed tomography view of unilateral condylar fracture after treatment.

25.0 software (IBM Corp., Armonk, NY, USA). Data were expressed in mean \pm standard deviation (SD), median (minmax), or number and frequency. The Shapiro-Wilk test, a histogram, and Q-Q plot were used to assess the data normality. The Levene test was used to examine the variance homogeneity. A two-sided one-way analysis of variance (ANOVA) was performed to compare significant differences between groups. Differences between trauma side and opposite side values were compared using the paired sample t-test. A P-value of $<0.05$ was considered statistically significant.

\section{RESULTS}

The ages of patients with condyle fractures ranged from 3 to 57 years (mean: 24.7, ss: 13.I). It was determined that 15 patients were 18 years old and under and 8 of them had SP VI fracture. In the etiology, it was determined that 14 of them were caused by traffic accident, 7 as a result of assault and 17 as a result of fall.

Six of the patients had bilateral condyle fractures and 32 patients had unilateral condyle fractures. 4 of the bilateral condyle fractures had SP VI, one was SP IV and VI, and the other had SP III and SP V fractures. Of the patients with unilateral condyle fractures, three had SP I, 10 had SP II, two had SP III, two had SP IV, eight had SP V, and seven had SP VI. The controls were performed 6 months after termination of active treatments. None of the patients developed ankylosis, open mouth, facial asymmetry, and retrognathia. The occlusion of the patients who were not known to have pre-trauma occlusions were directed, repositioned and provided an appropriate occlusion.

Five patients with bilateral condyle fractures had no negative symptoms after treatment. However, only one patient with

Table I . Results of Shapiro-Wilk test of normality

\begin{tabular}{lcccc}
\hline Side & Groups & Statistic & Degree of freedom & p-value \\
\hline Trauma side & IMF & 0.94 & 8 & 0.609 \\
& Occlusal Splint and IMF & 0.891 & $1 \mathrm{I}$ & 0.144 \\
Opposite side & Mini Plaque & 0.902 & 5 & 0.421 \\
& IMF & 0.909 & 8 & 0.348 \\
& Occlusal Splint and IMF & 0.964 & $1 \mathrm{I}$ & 0.821 \\
Mean difference & Mini Plaque & 0.853 & 5 & 0.203 \\
& IMF & 0.95 & 8 & 0.709 \\
& Occlusal Splint and IMF & 0.922 & $1 \mathrm{I}$ & 0.338 \\
& Mini Plaque & 0.92 & 5 & 0.531
\end{tabular}

IMF: Intermaxillary fixation. 
Table 2. Results of Test of Homogeneity of Variances

\begin{tabular}{lcccc}
\hline & Levene Statistic & dfl & df2 & p-value \\
\hline Opposite & 30.164 & 2 & 21 & 0.063 \\
Trauma & 0.234 & 2 & 21 & 0.793 \\
Difference & 0.198 & 2 & 21 & 0.822 \\
\hline
\end{tabular}

unilateral condyle fracture (SP V) developed laterognathy due to contraction of condyle size. The ramus length difference with the intact side was determined to be $13 \mathrm{~mm}$.

In Table I, the normality of the trauma side, opposite side and mean difference data of the groups was evaluated. According to the results of Shapiro-Wilk normality test, it is seen that group data provides normality for all three variables. Table 2 shows the homogeneity of the groups for trauma side, opposite side and mean difference values. According to the Levene test results, group variances are homogeneous. When the homogeneity of variances are evaluated together with normality tests, it is concluded that the data provide parametric assumptions.

The condyle lengths of the patients with unilateral fracture after recovery were compared with the intact side. The length between the most protruding point of the condyle and the mandible was measured on 3D CT. The length difference was only $5.94 \mathrm{~mm}$ for 8 patients who were treated by IMF; the length difference of the II patients whose brackets and splints were used and the measurements were made on their tomography was $3.36 \mathrm{~mm}(p<0.05)$ (Table 3). The length difference of 5 patients who were repaired and measured by plate screw was $1.80 \mathrm{~mm}(\mathrm{p}>0.05)$ (Table 3$)$. It was determined that the height difference was $13 \mathrm{~mm}$ in one patient and laterognathy was seen in this patient, not included in the calculation in order not to affect the statistical evaluation. In the IMF and IMF and Occlusal Splint groups, the opposite side values are statistically higher $(p<0.05)$ than the trauma side values (Table 3). Despite these statistical results, trauma-side and opposite-side values are statistically insignificant in comparison between groups $(p>0.05)$.

\section{DISCUSSION}

TME, which is a bone growth site, is different from other joints and has a unique movement order. Environmental factors affect the growth and development direction of the mandibular condyle. ${ }^{[26]}$ The areas of the condylar cartilage involved in the chewing function are thicker and the condyle growth direction is posteriosuperior. ${ }^{[27,28]}$ The treatment of condylar fractures depends on the age of the patient, the coexistence of other mandibular or maxillary fractures, whether the condylar fracture is unilateral or bilateral, the level and displacement of the fracture, and the status of dentition and dental occlusion. Therefore, it is considerable to evaluate the patient's signs and symptoms of trauma and identify the most appropriate treatment modality.

To date, there are some attempts to answer these questions and to select the most optimal treatment method. In a study, Balaji ${ }^{[29]}$ performed surgical treatment interventions for 55 unilateral and 20 bilateral condylar fractures during I-year follow-up, and four patients had limited mouth opening, while nine patients had temporary facial diathesis. In a prospective study, Sudheesh et al. ${ }^{[24]}$ examined the mandibular function after non-surgical treatment of unilateral subcondylar fractures in 30 patients. At 12 months of follow-up, they found minimal pain in the temporomandibular joint and an improvement in the perceived occlusion without reduced mouth opening. There was also no significant difference between the left and right lateral mandibular movements. The authors concluded that unilateral subcondylar fractures of the mandible could be treated non-surgically in patients with adequate mouth opening, minimal displacement of condyle, and minimal ramus height shortening. Takenoshita et al. ${ }^{[30]}$ compared 16 cases of condylar fracture treated surgically with 20 cases that were treated non-surgically (average follow-up was approximately 2 years) and found no significant functional differences between the two groups. Qureshi et al. ${ }^{[19]}$ reported that arch bars used in maxillary mandibular fixation are very effective treatment modality. Furthermore, Desai et al. ${ }^{[24]} 30$ patients operated with conservative approach. Conservative treatment approaches are preferred because they are more atrau-

Table 3. Comparisons of trauma side, opposite side and mean differences measurements according to groups

\begin{tabular}{|c|c|c|c|c|c|c|c|}
\hline \multirow[b]{2}{*}{ Groups } & \multirow[b]{2}{*}{$\mathbf{N}$} & \multicolumn{2}{|c|}{ Trauma Side } & \multicolumn{2}{|c|}{ Opposite Side } & \multirow{2}{*}{$\begin{array}{c}\begin{array}{c}\text { Mean } \\
\text { Difference }\end{array} \\
\text { Mean } \pm \text { SD }\end{array}$} & \multirow[t]{2}{*}{ Test Statistics $^{\dagger} \mathbf{p}$-value } \\
\hline & & Mean $\pm S D$ & Min-Max & Mean $\pm S D$ & Min-Max & & \\
\hline IMF & 8 & $59.81 \pm 9.23$ & $43-72.5$ & $65.75 \pm 9.98$ & $47-78$ & $5.94 \pm 2.45$ & $t=6.838 ; p<0.001$ \\
\hline Occlusal Splint and IMF & 11 & $58.73 \pm 8.63$ & $46-78$ & $62.09 \pm 7.67$ & $48-72$ & $3.36 \pm 4.41$ & $\mathrm{t}=2.529 ; \mathrm{p}=0.030$ \\
\hline Mini Plaque & 5 & $63.6 \pm 7.02$ & $54-71$ & $65.4 \pm 2.61$ & $63-69$ & $1.80 \pm 4.97$ & $t=0.810 ; p=0.463$ \\
\hline Test Statistics* & & $F=0.564$ & & $F=0.595$ & & $\mathrm{~F}=\mathrm{I} .828$ & \\
\hline P-value & & $p=0.577$ & & $\mathrm{p}=0.56 \mathrm{I}$ & & $p=0.185$ & \\
\hline
\end{tabular}

tPaired Sample t-test, " ANOVA: One way Analysis of Variance, significant $(p<0.05)$. IMF: Intermaxillary fixation; SD: Standard deviation. 
matic and can be more easily tolerated by the patient. Many researchers have reported that they have received conclusive results in treatments with occlusal splint. ${ }^{[31-34]}$

In another study, Wu et al. ${ }^{[35]}$ evaluated the effectiveness of the screw-based intermaxillary traction combined with occlusal splint in the treatment of pediatric MCFs. They observed no screw-related complication in the patients, except for one case of screw loosening. They concluded that the screw-based intermaxillary traction combined with occlusal splint could be an effective method for pediatric MCFs. In a case report, Xu et al. ${ }^{[36]}$ presented a pediatric case of bilateral condylar fracture which was treated with conservative fixed orthodontic approach and concluded that conservative treatment of MCFs through this method was effective. In the treatment of anterior disc dislocation, which may also occur due to a traumatic etiology, forward positioning splints are very effective. ${ }^{[37]}$ Several authors also reported that treatment with occlusal splint yielded good functional outcomes with minimal morbidity. ${ }^{[3 \mid-34]}$ In their study, Konaş et al. ${ }^{[38]}$ showed that bone healing was completed without any major complications with 4 to 6 weeks of IMF using occlusal splint. Consistent with the literature, in our study, the patients were treated conservatively using orthodontic bracket systems and satisfactory outcomes are achieved.

In recent years, many maxillomandibulary fixation techniques have been developed, and most of researchers have advocated that the arch bar is the most effective option in the treatment of condylar fractures. ${ }^{[19]}$ Orthodontic bracket systems work just like arch bars in the fixation of fractures with the advantage of less gingival damage. Due to the extreme displacement and rotation of the mandible in uni or bilateral condylar fractures, applying forces in different directions with brackets is way easier and gives more successful results. Comparing to the arch bars, bracket systems are less traumatic and more acceptable for patients. In a systematic review, Bruckmoser and Undt ${ }^{[39]}$ provided a comprehensive review of all types of case reports and clinical studies regarding the management and outcome of MCFs in children and adolescents and included 73 articles. Despite common radiological abnormalities, conservative management of condylar fractures in children often ended up with satisfactory to excellent clinical results. However, the outcomes were less favorable in adolescents. In our study, satisfactory results were obtained as assessed by physical examination. According to the radiographic evaluation, the length of the ramus was higher in patients with IMF and occlusal splints than those followed only by IMF, but less than patients with mini plate screws, on the other hand, the difference between the trauma side and the opposite side was not statistically significant $(p>0.05)$.

The main advantage of conservative treatment is to avoid postoperative infection. In a single-center, retrospective study, Domingo et al. ${ }^{[0]}$ investigated possible risk factors for infection following mandibular fracture surgery and found a significant increase in the risk of infection with open surgical management compared to closed reduction (I6.3\% vs. $3.2 \%$; $\mathrm{p}=0.000 \mathrm{I})$. In another study, Lizuka et al. ${ }^{[4 I]}$ reported that I3 of 214 patients with mandibular fractures treated in accordance with the Arbeitsgemeinschaft Osteosynthesefragen/ Association for the Study of Internal Fixation principle of rigid fixation developed postoperative infection and except one of the cases, all infected fractures were located in the angular region of the mandible. In our study, no signs of postoperative infection were observed.

ORIF is the gold standard for displaced condylar fractures, but there are certain disadvantages such as failure of the pins, technical difficulties in the placement of the condyle fragments, injury to the facial nerve, and a recovery period of about 3 months. ${ }^{[42]}$ Traumatic dislocation of the mandibular condyle from the middle cranial fossa is rarely seen as a result of maxillofacial injuries. ${ }^{[33]}$ However, the occlusion of the condyle in the fossa did not occur with the help of occlusal splints. Mcleod and Saeed ${ }^{[42]}$ presented their early clinical experience on the treatment of MCFs through ultrasound-activated resorbable pins, a relatively novel method, and no pins failed and there was no sign of instability during healing. In our study, none of the patients treated with mini-plate screws had facial nerve injury or long-lasting difficulties in recovery period.

The main limitation of the present study is different IMF techniques used. Since patients with different ages and dental conditions were treated, the costs of the IMF techniques also varied, and we had some difficulty in applying the same IMF method to each patient, as health insurance does not cover the brackets. Small sample size and retrospective nature of the study can be deemed as the other limitations. Therefore, further large-scale, multi-center studies are needed to confirm these findings.

COVID-19 has spread all over the world very quickly, and its spread capacity has affected even the most resilient health systems. Overall, $20 \%$ of cases are severe or critical, with a crude clinical case fatality rate currently of over $3 \%$, increasing in older age groups and in those with certain underlying conditions. Furthermore, this pandemic shook up health and social care systems and measures taken to control transmission have widen which caused socio-economic consequences. [43] The fact that this non-invasive treatment method gives good results in patients with condyle fractures gave hope in terms of the advantage provided to health workers in this period. During the pandemic period, hospitals need full capacity facilities to take care of pandemic cases and the treatment of non-urgent cases should be postponed to prevent cross infection. In addition, health centers experience serious problems in routine treatment procedures during this period and they try to adapt to this new situation by updating daily protocols and procedures. Here, one of the most important advantages of our technique in pandemic conditions is that it is a conservative treatment method that can be applied by or- 
thodontics department which is not a primary diagnosis and treatment provider in pandemic cases. So that, without both occupying the hospitals and affecting the number of physicians and healthcare workers dealing with the pandemic, this highly practical and non-invasive method can be performed on the condylar fracture patients as an outpatient service at the same hospital with COVID-I 9 infected individuals, on the condition that with all cautions taken.

\section{Conclusion}

In our study, the use of IMF with an occlusal splint is a more conservative and more acceptable treatment modality than open reduction. The most advantageous aspect of this method that none of the patients suffered from lack of mouth opening, ankylosis, open-bite, and retrognathia. To prevent the development of laterognatia in some patients, directing the lower jaw to the side of the intact condyle or anterior protrusion may be a preventive procedure advantageous to prevent the occurrence of this partial problem that may develop in some patients. In addition, as compared with the patients that were treated with only IMF, radiologically the obtained height of the ramus makes us think about its protective feature.

In such widespread outbreaks, one of the most important advantages of the technique we recommend is this method that can be applied by orthodontics department which is not primarily involved in the treatment of pandemic cases. The patients can be treated and discharged in the same day and in the same hospital with COVID-19 infected individuals, of course with all cautions taken, as the cross-infection risk is highly reduced.

Ethics Committee Approval: This study was approved by the Marmara University Faculty of Medicine Clinical Research Ethics Committee (Approval number: 09-2020-206, date: 06.03.2020).

\section{Peer-review: Internally peer-reviewed.}

Authorship Contributions: Concept: Ö.ç., N.D.K.; Design: Ö.Ç., N.D.K.; Supervision: Ö.Ç., N.D.K.; Resource: B.K.Ü., B.K.; Materials: B.K.Ü., M.Ç.Ö.; Data: B.K.Ü., B.K.; Analysis: B.K.Ü., M.Ç.Ö.; Literature search: B.K.Ü., N.D.K.; Writing: B.K.Ü., N.D.K.; Critical revision: Ö.Ç., N.D.K.

\section{Conflict of Interest: None declared.}

Financial Disclosure: The authors declared that this study has received no financial support.

\section{REFERENCES}

1. Marker P, Nielsen A, Bastian HL. Fractures of the mandibular condyle. Part 2: Results of treatment of 348 patients. Br J Oral Maxillofac Surg 2000;38:422-6. [CrossRef]

2. Motamedi MH. An assessment of maxillofacial fractures: A 5-year study of 237 patients. J Oral Maxillofac Surg 2003;61:61-4. [CrossRef]

3. Van Den Bergh B, Heymans MW, Duvekot F, Forouzanfar T. Treatment and complications of mandibular fractures: A 10-year analysis. J Cranio- maxillofac Surg 2012;40:e108-11. [CrossRef]

4. Palmieri C, Ellis E 3rd, Throckmorton G. Mandibular motion after closed and open treatment of unilateral mandibular condylear process fractures. J Oral Maxillofac Surg 1999;57:764-75, discussion 775-6.

5. Park JM, Jang YW, Kim SG, Park YW, Rotaru H, Baciut G, et al. Comparative study of the prognosis of an extracorporeal reduction and a closed treatment in mandibular condylee head and/or neck fractures. J Oral Maxillofac Surg 2010;68:2986-93. [CrossRef]

6. Sharif MO, Fedorowicz Z, Drews P, Nasser M, Dorri M, Newton T, et al. Interventions for the treatment of fractures of the mandibular condyle. Cochrane Database Syst Rev 2010 ;4:CD006538. [CrossRef]

7. Yang WG, Chen CT, Tsay PK, Chen YR. Functional results of unilateral mandibular condylear process fractures after open and closed treatment. J Trauma 2002;52:498-503, [CrossRef]

8. Bormann KH, Wild S, Gellrich NC, Kokemuller H, Stuhmer C, Schmelzeisen R, et al. Five-year retrospective study of mandibular fractures in Freiburg, Germany: Incidence, etiology, treatment, and complications. J Oral Maxillofac Surg 2009;67:1251-5. [CrossRef]

9. Niezen ET, Bos RR, de Bont LG, Stegenga B, Dijkstra PU. Complaints related to mandibular function impairment after closed treatment of fractures of the mandibular condylee. Int J Oral Maxillofac Surg 2010;39:660-5.

10. Silvennoinen $U$, Raustia AM, Lindqvist C, Oikarinen K. Occlusal and temporomandibular joint disorders in patients with unilateral condylear fracture. A prospective one-year study. Int J Oral Maxillofac Surg 1998;27:280-5. [CrossRef]

11. Gupta M, Iyer N, Das D, NagarajJ. Analysis of different treatment protocols for fractures of condylear process of mandible. J Oral Maxillofac Surg 2012;70:83-91. [CrossRef]

12. Chen CT, Feng CH, Tsay PK, Lai JP, Chen YR. Functional outcomes following surgical treatment of bilateral mandibular condylear fractures. Int J Oral Maxillofac Surg 2011;40:38-44. [CrossRef]

13. Bhagol A, Singh V, Kumar I, Verma A. Prospective evaluation of a new classification system for the management of mandibular subcondylear fractures. J Oral Maxillofac Surg 2011;69:1159-65. [CrossRef]

14. Zachariades N, Mezitis M, Mourouzis C, Papadakis D, Spanou A. Fractures of the mandibular condylee: A review of 466 cases. Literature review, reflections on treatment and proposals. J Craniomaxillofac Surg 2006;34:421-32. [CrossRef]

15. Forouzanfar T, Lobbezoo F, Overgaauw M, de Groot A, Kommers S, van Selms M, et al. Long-term results and complications after treatment of bilateral fractures of the mandibular condyle. Br J Oral Maxillofac Surg 2013;51:634-8. [CrossRef]

16. Choi KY, Yang JD, Chung HY, Cho BC. Current concepts in the mandibular condyle fracture management part I: Overview of condylear fracture. Arch Plast Surg 2012;39:291-300. [CrossRef]

17. Schneider M, Eckelt U. Classification of condylear process fractures. J Can Dent Assoc 2006;68:10-5.

18. Spiessl B, Schroll K. Spezielle Frakturen und Luxationslehre. A Short Manual In Five Volumes. Volume I / 1 Facial Skull. Stuttgart, New York: Georg Thieme Publishing House; 1972. p. 317.

19. Qureshi AA, Reddy UK, Warad NM, Badal S, Jamadar AA, Qurishi N. Intermaxillary fixation screws versus Erich arch bars in mandibular fractures: A comparative study and review of literatüre. Ann Maxillofac Surg 2016;6:25-30. [CrossRef]

20. Farronato G, Grillo ME, Giannini L, Farronato D, Maspero C. Longterm results of early condylear fracture correction: Case report. Dent Traumatol 2009;25:e37-42. [CrossRef]

21. Lloyd T, Nightingale C, Edler R. The use of vacuum-formed splints for temporary intermexillary fixation in the management of unilateral con- 
dylear fractures. Br J Oral Maxillofac Surg 2001;39:301-3. [CrossRef]

22. Mavili ME. Titanium screw implants for intermaxillary fixation of partially edentulous jaw. Ann Plas Surg 1997;39:353-9. [CrossRef]

23. Hardt N, Gottsauner A. The treatment of mandibular fractures in children. J Craniomxillofac Surg 1993;21:214-9. [CrossRef]

24. Sudheesh KM, Desai R, Sn SB, Subhalakshmi S. Evaluation of the mandibular function, after nonsurgical treatment of unilateral subcondylear fracture: A 1-year follow-up study. Craniomaxillofac Trauma Reconstr 2016;9:229-34. [CrossRef]

25. Defabianis P. TMJ fractures in children and adolescents: Treatments guidelines. J Clin Pediatr Dent 2003;27:191-9.

26. Karadede MI. Mandibular kondil histo anatomisinin ratlarda incelenmesi. D Ü Dişhek Fak Der 1995;6:1-6.

27. Karadede Mİ. Mandibular kondilin gelişim ve büyümesi kondilin gelişim ve büyümesi. D Ü Dişhek Fak Der 1995;6:7-10.

28. Karadede B, Karadede B, Karadede Mİ. In: Kalinowska IR, Orhan K, editors. Imaging of the Temporamandibular Joint, Bölüm adı: Growth, Development and Ossification of Mandible and Temporomandibular Joint. Vol. 1. Berlin: Springer 2019. p. 43-57. [CrossRef]

29. Balaji SM. Modified endural approach fort the treatment of condylear fractures: A review of 75 cases. Indian J Dent Res 2016;27:305-11.

30. Takenoshita Y, Ishibashi H, Oka M. Comparison of functional recovery after nonsurgical and surgical treatments of condylear fractures. J Oral Maxillofac Surg Nov 1990;48:1191-5. [CrossRef]

31. Liu CK, Tan XY, Xu J, Liu HW, Liu SX, Hu M. Evaluation of the clinical results of non-surgical treatment for pediatric sagittal fracture of mandibular condylee. Zhonghua Kou Qiang Yi Xue Za Zhi 2013;48:641-4.

32. Liu CK, Meng FW, Tan XY, Xu J, Liu HW, Liu SX et al. Clinical and radiological outcomes after treatment of sagital fracture of mandibular condylee (SFMC) by using occlusal splint in children. Br J Oral Maxillofac Surg 2014;52:144-8. [CrossRef]

33. Boffano P, Roccia F, Schellino E, Baietto F, Gallesio C, Berrone S. Con- servative treatment of unilateral displaced condylear fractures in children with mixed dentition. J Craniofac Surg. 2012;23:e376-8. [CrossRef]

34. Zhao YM, Yang J, Bai RC, Ge LH, Zhang Y. A retrospective study of using removable occlusal splints in the treatment of condylear fracture in children. J Craniomaxillofac Surg 2014;42:1078-82. [CrossRef]

35. Wu Y, Long X, Deng M, Cai H, Meng Q, Li B. Screw-based intermaxillary traction combined with occlusal splint for treatment of pediatric mandibular condylear fracture. Zhongguo Xiu Fu Chong Jian Wai Ke Za Zhi 2015;29:397-401.

36. Xu Y, Gong SG, Zhu F, Li M, Biao X. Conservative orthodontic fixed appliance management of pediatric mandibular bilateral condylear fracture. Am J Orthod Dentofacial Orthop 2016;150:181-7. [CrossRef]

37. Kaya B, Karadede Mİ. Temporomandibular eklem diskinin anterior dislokasyonunun tedavisinde öne konumlandırıcı splintlerin etkinliğinin araştırılması. Dicle Tip Derg 1999;26:39-48.

38. Konaş E, Tunçbilek G, Kayıkçıŏlu A, Akcan CA, Kocadereli İ, Mavili ME. Splint-assisted reduction of comminuted maxilllofacial fractures. J Craniofac Sug 2011;22:1471-5. [CrossRef]

39. Bruckmoser E, Undt G. Management and outcome of condylear fractures in children and adolescents: A review of the literature. Oral Surg Oral Med Oral Pathol Oral Radiol 2012114 Suppl 5:S86-106. [CrossRef]

40. Domingo F, Dale E, Gao C, Groves C, Stanley D, Maxwell RA, et al. A single-center retrospective review of postoperative infectious complications in the surgical management of mandibular fractures: Postoperative antibiotics add no benefit. J Trauma Acute Care Surg 2016;81:1109-14.

41. Lizuka T, Lindqvist C, Hallikainen D, Paukku P. Infection after rigid internal fixation of mandibular fractures: A clinical and radiologic study. J Oral Maxillofac Surg 1991;49:585-93. [CrossRef]

42. McLeod NM, Saeed NR. Treatment of fractures of the mandibular condylear head with ultrasound-activated resorbable pins: Early clinical experience. J Oral Maxilllofac Surg 2016;54:872-7. [CrossRef]

43. World Health Organization. Covid-19 Strategy Update, Draft as all 13 April 2020. Geneva: World Health Organization; 2020.

\section{ORIJIINAL ÇALIŞMA - ÖZ}

\section{Mandibula kondil kırıklarında farklı tedavi tekniklerin karşılaştırılması}

\section{Dr. Nihal Durmus Kocaaslan, ${ }^{1}$ Dr. Beyza Karadede Ünal, ${ }^{2}$ Dr. Melekber Çavuş Özkan, ${ }^{1}$ Dr. Berşan Karadede, ${ }^{2}$ Dr. Özhan Çelebiler ${ }^{1}$}

\section{${ }^{1}$ Marmara Üniversitesi Tıp Fakültesi, Rekonstrüktif, Estetik ve Plastik Cerrahi Anabilim Dalı, İstanbu} ${ }^{2}$ İzmir Katip Çelebi Üniversitesi Diş Hekimliği Fakültesi, Ortodonti Anabilim Dalı, İzmir

AMAÇ: Mandibula kondil kırıkları, intermaksiller fiksasyon (IMF) ile konservatif olarak veya açık redüksiyon ile tedavi edilmektedir. Birçok çalışmada bu tip kırıklar için optimal tedavi yöntemi tartışılmıştır. Bu çalışmada, mandibuladaki kondil kırıklarında uygulanabilecek konservatif teknikler ile cerrahi tekniğin karşılaştırılması amaçlanmıştır.

GEREÇ VE YÖNTEM: Çalışmamızda I8-24 yaş arası kondil boynu kırı̆̆ı tanısı konualarak üç farklı tedavi yöntemi ile tedavi edilmiş toplam 24 hastanın ameliyat öncesi ve sonrası arşiv bilgisayarlı tomografı kayıtları kullanıımıştır. Cerrahi müdahale uygulanmayan hastaların yaşına ve dişsel durumuna bağlı olarak intermaksiller fiksasyon (IMF) yapılabilmesi için toplamda 19 hastaya braketleme, ark bar ya da mini vida uygulanmış; sekiz adet hastaya sadece ortodontik IMF, II hastaya ise tek veya çift taraflı yükselticili okluzal splint IMF ile birlikte uygulanmıştır. Ayrıca beş hastaya da mini plak ile açık redüksiyon uygulanmıştır. Ortodontistler ve cerrahlar tarafından, klinik ve radyolojik olarak hastaların ameliyat öncesi ve altı aylık ameliyat sonrası değerlendirmeleri yapılmıştır.

BULGULAR: Tek tarafı kondil boynu kırığı olan hastalarda, iyileşme sonrasında, kondil ve mandibula'nın en çıkıntılı noktaları arasındaki uzaklık, etkilenmeyen taraf ile karşılaştırılarak IMF ile tedavi edilen hastalarda uzunluk farkı sadece $5.94 \mathrm{~mm}$; braket ve splint uygulanan hastalardaki uzunluk farkı $3.36 \mathrm{~mm}(p<0.05)$; vidalı plaklar ile tedavi edilen hastalardaki uzunluk farkı I.80 mm ( $>>0.05)$ olarak tespit edilmiştir. Lakin IMF, Oclusal Splint \& IMF ve Mini Plak gruplarının, travma tarafı ve karşı taraf arasındaki karşış̧tırmalarda gruplar arasında istatistiksel olarak anlamlı bir fark ( $p>0.05$ ) bulunmamıştır. Travma öncesi oklüzyonları bilinmeyen hastaların oklüzyonlar ortodontist tarafından yeniden konumlandırıldı ve hiçbir hastada ankiloz, açık kapanış, ağız açmada kısıtlılık, fasiyal asimetri, laterognati veya retrognati görülmemiştir.

TARTIŞMA: Uygun olgularda IMF'nin oklüzal splint ile uygulanması, açık redüksiyondan daha konservatif ve kabul edilebilir bir tedavi yöntemidir. Anahtar sözcükler: Covid-19; kondil kırı̆̆і; konservatif tedavi; salgın; splint; temporomandibular eklem. 